\title{
Elaboration of a natural sweetener using Erythritol/Stevia
}

\author{
Ivisson de Souza TASSO ${ }^{1}$ (D), Thaís Gentiluce dos SANTOS $^{1}$ (D), Neusa Fátima SEIBEL ${ }^{1}$ (D)
}

\begin{abstract}
The food industry always searches for innovation, product improvement, quality and customer satisfaction. In relation to sweeteners, this search had an expressive increase in recent times due to the increase of diseases caused by the excessive consumption of sugar. Most tabletop sweeteners marketed in Brazil have bulking agents with characteristics not appreciated by consumers, substances that can cause intolerance such as lactose or caloric products such as maltodextrin $(4 \mathrm{kcal} / \mathrm{g})$. Considering this problem, the aim of the research was to develop a natural sweetener, without contraindications, using the erythritol / stevia blend to compose the formulation. Three formulations (standard, $10 \%$ sweeter and $10 \%$ less sweet) were developed, that in the sorting test there was no preferred sample, being able to opt for the formulation with lower cost - $10 \%$ less sweet. At the same time, a semistructured questionnaire was applied, characterizing the consumers of sweeteners. Of all respondents, $43 \%$ used sweeteners. The variable that increases the chance of its consumption is "being overweight"; when associated with the variable "overweight family", the chance of consumption is greater. Another proof was that more than $40 \%$ of users search for natural substances in their sweetener, strengthening the possibility of developing a natural sweetener.
\end{abstract}

Keywords: erythritol; polyol; sweeteners; sensory analysis; glycosides of esteviol.

Practical Application: The food industry is increasingly seeking to improve sugar substitutes, along with the demand for natural products which is a trend. The objective of this paper was to describe the development of three formulations of tabletop sweeteners with natural substances and to choose one using sensory analysis techniques (preference ordering test). In addition, the study characterized the users through a questionnaire, using a sample for convenience, demonstrating which variables influence consumption or not.

\section{Introduction}

Food is something of great importance in everyday life, besides meeting basic physiological needs, it comprehends economic, social, scientific, political, cultural and psychological aspects (Proença, 2010). Regardless of sociocultural aspects, the sweet taste motivates all ages, races and cultures. This food preference is part of human evolution, since food rich in energy and nutrients had this sensorial characteristic (Reed \& McDaniel, 2006).

Sucrose, popularly known as sugar, is one of the major sources of sweet taste, but excessive consumption of this substance may increase the risk of chronic diseases, such as diabetes (Yang, 2010). In order to serve consumers who are interested in the sweet taste, without the consequences of excessive consumption of sucrose, tabletop sweeteners have appeared. These are defined as the "product formulated to confer sweet taste to foods and beverages, constituted of sweetener (s) provided in technical regulation. The use of the intended bulking agent(s) is permitted ". Tabletop sweeteners may contain the following bulking agents in their composition: ethyl alcohol, starches, water, modified starches; dextrins; dextrose; fructo-oligosaccharides; isomalto-oligosaccharides; fructose and its syrups; glucose syrup; glycerol or glycerol; isomalte; lactose; maltitol and its syrup; maltodextrin; mannitol; polydextrose; polyethylene glycol; propylene glycol; sucrose; sorbitol; and others provided for in specific Technical Regulations (Brasil, 2005). Among the sweeteners, it is possible to use substances such as: acesulfame, aspartame, cyclamates and their salts, saccharin and its salts, sucralose, thaumatin, steviol and neotame glycosides (Brasil, 2008).

The safety, solubility, stability, sensory profile close to sucrose and its cost are the main aspects evaluated in the choice of sweeteners (Casarotti, 2009). Considering these characteristics is of great importance to meet an increasingly demanding market. Another feature in the development of sweeteners is the blend of molecules (blend), which provides a synergistic effect, improving costs and sensorial characteristics (Simony \& Geraldo, 2014).

The national market offers numerous combinations of sweeteners and bulking agents in tabletop sweeteners. The most used bulking agents in Brazil are maltodextrin and lactose. Maltodextrin offers $4 \mathrm{kcal} / \mathrm{g}$ and lactose can cause intestinal discomfort to people intolerant to it. Due to these characteristics, other substances have gained prominence in Brasil Foods Trends 2020 (Federação das Indústrias do Estado de São Paulo, 2010), inputs such as: Erythritol, Lactitol, Taumatine, Stevia and Glicerrizinato highlighted the health and fitness market in "health and wellness".

Erythritol is a polyol that has only $0.2 \mathrm{kcal} / \mathrm{g}$ (Brasil, 2010) and it is natural, low glycemic index (Livesey, 2012), obtained by 
fermentative processes, without side effects and low absorption by the organism, $90 \%$ is eliminated in the urine (Grembecka, 2015), and the effects of the treatment on the gastrointestinal tract. As stevia is extracted from a plant of the same name, it has antioxidant and antihypertensive activity, among other benefits (Carvalho, 2017), but one can not disregard the characteristic bitter residual taste (Osman et al., 2013).

This study aimed to characterize the consumers of sweetener, their habits, to understand their motivations and preferences of choice, as well as to develop a natural sweetener using blend stevia and erythritol and to grasp whether, through the results of the questionnaire, such product can be accepted by them. The coffee was chosen for the tests because it is the second most consumed drink in Brazil (Empresa Brasileira de Pesquisa Agropecuária, 2018) and in industrial tests the sweetener is applied in it, since it is in this drink that the majority of the consumption happens.

\section{Materials and methods}

\subsection{Development and application of the questionnaire}

A semi-structured questionnaire was developed, containing questions about demographic data and about the consumption habits of sweeteners. The questionnaire contained 23 questions. The first 10 questions were answered by consumers and not consumers of sweeteners. From question 11, only the users of sweeteners answered specific questions of the theme. The questions were based and adapted from the following authors: Campos et al. (2012); Oliveira \& Franco (2010); Zanini et al. (2011); Marques et al. (2012); Saito et al. (2013); Geraldo \& Pinto-e-Silva (2016); and Santos et al. (2017).

The application of the questionnaire was through the use of social networks, having as prerequisite to be over 18 years old. Due to the use of the virtual means, the results generated a sample for convenience, that is, it selected a population that was accessible by the existing network of contacts of the applicators.

The questions addressed the following variables: gender, age, marital status, overweight, sports, the use of sweetener, composition, if the person has changed sweetener and why, overweight family, whether the person likes it or not and why he/she does not like, how it was chosen, how it is used, what foods it is used, income, number of people in the household, frequency of use and frequency of purchase, and age. The questionnaire was approved by the Ethics Committee (CEP) of UTFPR (Process CAAE no 86817418.1.0000.5547)

\subsection{Material for the preparation of the table-top sweetener}

The development of the sweetener is consisted of: Erythritol- brand Vida em Grãos ${ }^{\circledR}$ - Steviol Glycosides and Silicon Dioxide - donated by Stevia Natus Natural Products.

\subsection{Development of the sweetener}

Three formulations of sweeteners were developed containing erythritol, steviol glycosides and silicon dioxide The first formulation followed the recommendations of the supplier of steviol glycosides and silicon dioxide, the remainder of the volume in the formulation being erythritol, in the other two formulations had $10 \%$ more and $10 \%$ less sweetness variation respectively by dosing of glycosides of esteviol (Table 1).

As the market works with specific characteristics of the products, empirical research was conducted in online markets to determine the weight per dose. It was found that tabletop powder sweeteners which contained stevia as the main sweetening molecule normally had the net weight of $0.6 \mathrm{~g}$ of sweetener per dose. Because of this, the same weight was used for this study.

Erythritol was weighed on a semi-analytical balance (Bel Engineering brand Mark 2200 ${ }^{\circledR}$, Londrina, Brasil), steviol glycosides and silicon dioxide on analytical balance (Shimadzu brand, model ATY224 ${ }^{\circledR}$, Londrina, Brasil). The homogenization was carried out in bags, it was closed hermetically by means of welding and applied circular movements for 5 minutes, simulating the effect of an industrial mixer.

\subsection{Microbiological evaluation}

The microbiological evaluations were carried out in triplicate, in an outsourced and credited laboratory. For this research, studies were carried out regarding total Coliforms, according to the ISO 4832: 2006 methodology. According to what was established by the Board of Directors of the National 235 Agency of Sanitary Surveillance - ANVISA, item 11-C (Brasil, 2001)

\subsection{Physical and physical-chemical evaluations}

The samples were characterized in triplicate for moisture, density and wettability. The moisture of the elaborated sweeteners followed the method 925.45B (Association of Official Analytical Chemists, 2016), the density of the sweeteners was determined according to the methodology described by the Instituto Adolfo Lutz (2008), using a stainless steel pycnometer, this information is required to determine package dimensions. The wettability was determined and compared among commercial sweeteners containing maltodextrin / stevia and lactose / stevia, and in the formulation elaborated in this work, containing erythritol / stevia. 0.6 grams of sweetener was placed in $50 \mathrm{ml}$ of coffee at $60{ }^{\circ} \mathrm{C}$, measuring the time required for total immersion of the sweetener in the beverage.

\subsection{Sensory evaluation}

The tasters were summoned verbally, taking into account their interest and availability in the consumption of coffee with sweetener. The study was approved by the Ethics Committee (CEP) of UTFPR (Process CAAE n 86817418.1.0000.5547).

Table 1. Formulation of powered sweeteners (\%).

\begin{tabular}{|c|c|c|c|}
\hline \multirow[t]{2}{*}{ Formulation } & Erythritol & $\begin{array}{c}\text { Glycosides of } \\
\text { Esteviol }\end{array}$ & Silicon dioxide \\
\hline & $\%$ & $\%$ & $\%$ \\
\hline A & 87.83 & 11.67 & 0.5 \\
\hline B & 89.0 & 10.5 & 0.5 \\
\hline $\mathrm{C}$ & 86.67 & 12.83 & 0.5 \\
\hline
\end{tabular}

Source: Own authorship (2018). 
As described by Dutcosky (2013), three coffee samples sweetened with the Erythritol / Stevia blend were presented to be sorted by preference. The coffee was prepared following the Associação Brasileira da Indústria de Café (2018) methodology, with the proportion of 80 grams of roasted, ground, vacuum-packed, traditional type Pilão ${ }^{\circledR}$ brand for each litre of boiling water. In the filtration process, a paper filter with support was used, the beverage being stored in thermal bottles for a maximum of two hours. The coffee was sweetened with the A (standard), B (10\% sweeter) and C (10\% less sweet) formulations in the proportion of $0.6 \mathrm{~g}$ for each $50 \mathrm{ml}$. The samples were randomly served and the reviewers were asked to write in order from minus to the most preferred in a sensory record.

\subsection{Statistical analysis}

The data collected from both the questionnaire and the sensory were analyzed using Software R Project for Statistical, version 3.5.1. The statistical analysis of the questionnaire had the purpose of verifying which variables were significant for the consumption or not of the sweetener. Logistic regression was used for the adjustment of the statistical model. For the data correlations, Pearson's Chi-square test was applied. Already for the preference test, the results were analyzed using the Friedman test with the Christensen Table and associated, according to Dutcosky (2013).

\section{Results and discussion}

\subsection{Analysis of the questionnaire}

The survey consisted of 234 people of both sexes, with an average age of 35 years and the highest frequency between 30 and 40 years, being the sample for convenience, that is, a sample that was accessible by its availability (Anderson et al., 2007). The results obtained until question 10 showed characteristics of the respondents consumers or not of sweeteners. The chi-square test was applied to evaluate which variables influenced the consumption of sweetener (Table 2).

The study showed that $43 \%$ of respondents use sweeteners, more than $23 \%$ of respondents in the study Zanini et al. (2011). Geraldo \& Pinto-e-Silva (2016) showed that the odds of consuming sweeteners are 1.68 times higher among overweight people. By applying Pearson's Chi-square test in this study, the probability of consuming sweetener is 1.51 times higher among overweight respondents, showing a similarity in the results. This chance increased to 2.4 times when the variables "being overweight" and "overweight family" were associated.

Geraldo \& Pinto-e-Silva (2016) also concluded that the use of sweeteners is indicated for diabetics (73.7\%), obese (66.5\%), hypertensive (15.6\%), normal weight and for all people (32.1\%). On the other hand, the results of this research showed that: the healthiest lifestyle is that the interviewees are more interested in (52.5\%), followed by dieting (28.7\%), preference and / or practicality $(11.9 \%)$ and those who can not consume sugar (6.9\%). The researches showed some discrepancies that may be caused by the indicators suggested by the interviewers, change of habits and by the samples reached.
In a study on the consumption of sweeteners by hypertensives and diabetics, Cotta et al. (2009) found that $90 \%$ of the users used artificial sweeteners. However, those who use natural sweeteners $(21.8 \%)$ or blends between artificial and natural sweeteners $(18.8 \%)$ are higher than the ones that use artificial sweeteners (45.5\%). above $10 \%$. These results justified the variable "why consume sweetener" being the "healthietst lifestyle".

This research generated other results. Those interviewed who had already changed their sweeteners totalled $82.2 \%$; of those who have changed: $34.7 \%$ stated that they have done it by hearing "it is bad" what they consumed; and $15.8 \%$ have changed by hearing "it is good" another kind of sweetener. More than a half of the respondents (61.4\%) like the taste of the sweetener and those who don't, they blame the residual flavour (84.6\%).

The flavour still has the most influence on the choice of sweeteners $(35.6 \%)$, followed by being beneficial / natural (28.7\%), indication $(26.7 \%)$ and price $(8.9 \%)$. The increase in consumer interest in natural substances has been highlighted by Beltrami et al. (2018), but it also reminds us that natural sweeteners

Table 2. Characteristics of the interviewees on the consumption or not of sweeteners.

\begin{tabular}{|c|c|c|c|c|c|}
\hline & \multicolumn{2}{|c|}{ Do not use } & \multicolumn{2}{|c|}{ Use } & \multirow{2}{*}{$p$ value } \\
\hline & $\mathrm{n}$ & $\%$ & $\mathrm{n}$ & $\%$ & \\
\hline \multicolumn{6}{|l|}{ Sex } \\
\hline Male & 32 & 24.1 & 19 & 18.8 & \\
\hline Female & 101 & 75.9 & 82 & 81.2 & \\
\hline \multicolumn{6}{|l|}{ Age } \\
\hline 18 to 29 years & 36 & 27.1 & 26 & 25.7 & 0.329 \\
\hline 30 to 39 years & 70 & 52.6 & 51 & 50.5 & \\
\hline 40 to 49 years & 21 & 15.8 & 16 & 15.8 & \\
\hline 50 to 59 years & 3 & 2.3 & 1 & 1.0 & \\
\hline 60 to 69 years & 3 & 2.3 & 7 & 6.9 & \\
\hline \multicolumn{6}{|l|}{ Marital Status } \\
\hline Single & 57 & 42.9 & 36 & 36.7 & 0.332 \\
\hline Married & 66 & 49.6 & 52 & 53.1 & \\
\hline Divorced & 10 & 7.5 & 9 & 9.2 & \\
\hline Widow/Widower & 0 & 0.0 & 1 & 1.0 & \\
\hline \multicolumn{6}{|l|}{ Schooling } \\
\hline High school & 4 & 3.0 & 0 & 0.0 & 0.265 \\
\hline College & 50 & 37.6 & 34 & 34.0 & \\
\hline Postgraduate & 79 & 59.4 & 66 & 66.0 & \\
\hline \multicolumn{6}{|l|}{ Income (wages) } \\
\hline Up to 1 & 1 & 0.8 & 12 & 10.1 & 0.209 \\
\hline From 1 to 3 & 20 & 15.0 & 8 & 6.7 & \\
\hline From 3 to 6 & 33 & 24.8 & 22 & 18.5 & \\
\hline From 6 to 9 & 37 & 27.8 & 28 & 23.5 & \\
\hline From 9 to 12 & 17 & 12.8 & 22 & 18.5 & \\
\hline More than 12 & 25 & 18.8 & 27 & 22.7 & \\
\hline \multicolumn{6}{|l|}{ Overweight } \\
\hline Yes & 53 & 39.8 & 61 & 60.4 & 0.003 \\
\hline No & 80 & 60.2 & 40 & 39.6 & \\
\hline \multicolumn{6}{|l|}{ Practices sports } \\
\hline Yes & 80 & 60.2 & 60 & 59.4 & 0.865 \\
\hline No & 53 & 39.8 & 41 & 40.6 & \\
\hline
\end{tabular}

Source: Own Authorship (2018). 
can compromise taste. It was observed that the purchase of the product occurs between one and two months (40.6\%), but a high number of respondents did not remember how much time they purchased (23.8\%), suggesting that people may use the sweetener for a longer time than the recommendations of the suppliers, which results in losses, in particular the sensorial ones.

The use is made by $40 \%$ of respondents once a day; $22.8 \%$ twice daily; and three or more times add up to $37.6 \%$. The dosage generated the following results: most put and experimented until reaching the desired flavor (65.3\%), or places without observing the quantity (13.9\%); only $16.8 \%$ follow the supplier's instructions. This unmeasured dosage is a complication, as excessive use of the sweetener increases the residual flavors creating possible consumer dissatisfaction with the product. Still with the emphasis on use, it was addressed "where they use" the sweetener. The results showed that $60.4 \%$ use in hot drinks (coffee and tea); $29.7 \%$ in hot and cold drinks (juices, iced tea); $5.9 \%$ in revenues and only $4 \%$ in cold drinks. The consumption in hot drinks is easy to correlate since coffee is the second most consumed beverage in Brazil (Empresa Brasileira de Pesquisa Agropecuária, 2018), but it has been noticed that the market has much to grow when exploring the consumption of sweeteners in the preparation of other formulations. The number of consumers who use it in hot drinks, such as coffee, justifies the choice of product to be tested in this drink.

Among the habits of the sweetener consumers, the associations of variables that presented a significant relationship at a level of 5\% were: Already changed from sweetener versus because it changed $(\mathrm{p}<0.001)$ until being related in the questionnaire. Already changed from sweetener versus sweetener choice $(p=0.006)$, this correlation refers to the characteristics of each variable, since the respondents stated that it was the unpleasant taste of what used to be the reason for the change and the flavor is more indicative in the purchase. Composition of sweetener versus frequency of sweetener use $(\mathrm{p}=0.006)$. Composition of sweetener versus sweetener $(\mathrm{p}=0.018)$ This correlation strengthens the indicative flavor in the choice, as well as the correlation Sweetener composition versus sweetener choice $(\mathrm{p}=0.019)$.

Decreasing daily calorie intake while consuming sweet foods with a sugar-like taste is a consumer's wish, a characteristic that drives the sweetener market every day (Beltrami et al., 2018). Another interesting feature is the growing search for natural substances in the sweeteners (Chung \& Lee, 2013; Suez et al., 2015), as an example of the formulations elaborated in this work.

\subsection{Development of the sweetener}

To develop a sweetener is not simply to weigh and mix the inputs, it must present both visual and palatable homogeneity, that is, the inputs must be distributed proportionally throughout the product avoiding phase difference, as well as larger and smaller sweetness caused by variation of the concentration of the sweetener in the product. Due to these characteristics, the product behaved satisfactorily since no apparent phases were found in the formulations containing the natural ingredients erythritol as bulking agent and stevia as sweetness, in addition to silicon dioxide as anti-humectant agent, commonly used in food.

\subsection{Microbiological and physicochemical evaluations}

The microbiological evaluations carried out on the sweetener samples complied with the requirements established by Brazilian legislation, which imposes a maximum limit of $2 \mathrm{CFU} / \mathrm{g}$. These respected the values established by the Board of Directors of the National Agency of Sanitary Surveillance - ANVISA, item 11-C (Brasil, 2001).

Physical-chemical analyzes are of paramount importance in the development of products, showing characteristics that guarantee the integrity or needs for its conservation. The mean results of moisture and density assessments are described in Table 3. Density is widely used by the packaging industry to determine the dimensions of the primary packaging (sachet) and the food industry considers moisture values below 7\% ideal to avoid possible stonework (industrial standard).

As most formulations are erythritol, the samples did not differ from each other, showing that regardless of the formulation, standard, or containing more or less sweetness, the moisture and density are similar.

The vehicles used in certain powdered sweeteners may impair their solubility, ie the powder floats on the surface of the liquid. The ability to penetrate is determined by the wettability, this is the time required for the powder to be absorbed by the liquid (Cavalcante, 2017). In view of this concept, it was decided to determine the wettability of the processed product by comparing commercial dietary sweeteners, with similar composition of high-power sweetener molecule and different bulking agents (Table 4).

The wettability test was interesting in two aspects. The first to show that the sweetener does not offer a supernatant, which is visually pleasing to the consumer; the second consists in comparing the time of the dipping powder in the coffee. The sweetener with erythritol had a similar time to that of sweetener with lactose carrier and lower than that with maltodextrin, showing that this characteristic is not an impediment to the product, that is, its wettability is similar to or better than dietary sweeteners

Table 3. Physical-chemical characterization of Erythritol / Stevia blends.

\begin{tabular}{ccc}
\hline Samples & Moisture $(\%)$ & Density $(\mathrm{g} / \mathrm{ml})$ \\
\hline A & $2.1^{\mathrm{a}} \pm 0.2$ & $0.81^{\mathrm{a}} \pm 0.05$ \\
B & $2.2^{\mathrm{a}} \pm 0.2$ & $0.82^{\mathrm{a}} \pm 0.04$ \\
C & $2.3^{\mathrm{a}} \pm 0.1$ & $0.81^{\mathrm{a}} \pm 0.05$ \\
\hline
\end{tabular}

A: standard; B: $10 \%$ sweeter; C: $10 \%$ less sweet. Averages \pm standard deviation. Means followed by the same letters in the columns did not differ significantly by the Tukey test (5\%). Source: Authorship (2018).

Table 4. Wettability test with sweeteners containing different bulking agents.

\begin{tabular}{lc}
\hline \multicolumn{1}{c}{ Sample } & Wettability \\
\hline Sweetener with Maltodextrin & $1.9^{\mathrm{ab}} \pm 0.1$ \\
Sweetener with Erythritol & $1.6^{\mathrm{ab}} \pm 0.1$ \\
Sweetener with Lactose & $1.5^{\mathrm{a}} \pm 0.2$ \\
\hline
\end{tabular}

Averages \pm standard deviation. Means followed by the same letters in the columns did not differ significantly by the Tukey test (5\%). Source: Authorship (2018). 
Table 5. Preference ordination test of Erythritol / Stevia blends.

\begin{tabular}{cc}
\hline Sample & Sum \\
\hline A & 117 \\
B & 127 \\
C & 128 \\
\hline
\end{tabular}

A: standard; B: 10\% sweeter; C: 10\% less sweet. Source: Own Authorship (2018).

that are already commercialized. The results of the sweetener physical-chemical characterizations and the wettability tests were evaluated by ANOVA and the Tukey test to the level of $5 \%$ of significance.

\subsection{Sensory analysis}

The sensorial evaluation was carried out with 60 tasters, a quantity requested by Dutcosky (2013), coffee consumers, being users or with interest in the consumption of sweeteners, using the preference ordering test (Table 5).

The Friedman test provided a $\mathrm{F}_{\text {test }}$ of 1.193548. The critical value of the Christensen Table and associated for 3 samples, 60 evaluators at $5 \%$ significance is 5.99 . It was observed that even though there were 3 different sweeteners, there was no significant difference in the preference of the evaluators.

The ratings resulted in some remarks on the records. Sample A (standard) generated few comments, some referring to residual and others that considered adequate sweetness. Of those who preferred sample B (less sweet), they mentioned that the sweetener did not interfere with the taste of the coffee; and those who did not choose, they found little sweet. Already the $\mathrm{C}$ (sweeter) was the one that had more comments on the residual flavor; of those who preferred it found the sweet taste appropriate.

In proportion, erythritol and silicon dioxide did not vary in the formulations (Table 1), but stevia presented the greatest differences. Knowing that this substance has the capacity both to sweeten and to leave residual taste can be considered that it is responsible for the preference of sweetness as well as for rejections by the residual taste.

Another point to note is that erythritol has a characteristic refreshing taste (Aditivos e Ingredientes, 2008), but no such mention has been made on any form. Based on this observation, it can be stated that erythritol was a bulking agent that did not interfere with the preference of table-top sweetener formulations when applied to coffee, other than stevia which causes significant changes in the perception of sweetness and residual taste.

\section{Conclusions}

The applied questionnaire showed that the tendency to use natural sweeteners is increasing when comparing with other studies; in addition, it has been realized that people are looking for a healthier lifestyle, without wanting to give up the taste; and considering yourself overweight is a factor that has increased the chances of consuming sweeteners, when associated with the overweight family this chance is even greater.

The present study showed that it is possible to develop a low-calorie, natural, no contraindications sweetener using the erythritol / stevia blend. Although presented in three formulations, with sweetness profiles different from the evaluators, the results showed that they did not differ statistically, being able to opt for the formulation with lower cost (10\% less sweetness). Erythritol has been shown to be an interesting bulking agent in sweeteners because it has similar or better wettability than normally encountered bulking agents, and does not create variation in sensory perceptions. The characteristic coolness of erythritol was not realized and comments on sweetness and residual taste were relevant to variations in stevia dosage.

\section{References}

Aditivos e Ingredientes. (2008). Os polióis. São Paulo: Editora Insumos. Retrieved from http://www.insumos.com.br/aditivos_e_ingredientes/ materias/81.pdf

Anderson, D. R., Sweeney, D. J., \& Williams, T. A. (2007). Estatística aplicada à administração e economia (2. ed.). São Paulo: Editora Cengage Learning.

Association of Official Analytical Chemists - AOAC. (2016). Official methods of analysis (20th ed.). Gaithersburg: AOAC.

Beltrami, M. C., Döring, T., \& Lindner, J. D. (2018). Sweeteners and sweet taste enhancers in the food industry. Food Science and Technology, 38(2), 181-187. http://dx.doi.org/10.1590/fst.31117.

Brasil, Ministério da Saúde. (2001, January 2). RDC no 12, de 02 de janeiro de 2001. Aprova Regulamento Técnico sobre Padrões Microbiológicos para Alimentos. Diário Oficial da República Federativa do Brasil.

Brasil, Ministério da Saúde. (2005, September 22). RDC nº 271, de 22 de setembro de 2005. Aprova Regulamento Técnico para Açúcares e Produtos para Adoçar. Diário Oficial da República Federativa do Brasil.

Brasil, Ministério da Saúde. (2008, March 24). RDC nº 18, de 24 de março de 2008. Dispõe sobre o Regulamento Técnico que Autoriza o Uso de Aditivos Edulcorantes em Alimentos, com seus Respectivos Limites Máximos. Diário Oficial da República Federativa do Brasil.

Brasil, Ministério da Saúde. (2010, November 5). RDC no 48, de 05 de novembro de 2010. Dispõe sobre o Fabor de Conversão Para o Cálculo do Valor Energético do Eritritol. Diário Oficial da República Federativa do Brasil.

Empresa Brasileira de Pesquisa Agropecuária - EMBRAPA. (2018). Café é a segunda bebida mais consumida no Brasil. Brasília: EMBRAPA. Retrieved from https://www.embrapa.br/cafe/busca-de-noticias/-/ noticia/2574254/cafe-e-a-segunda-bebida-mais-consumida-no-brasil

Associação Brasileira da Indústria de Café - ABIC. (2018). O café: dicas gerais. Rio de Janeiro: ABIC. Retrieved from http://abic.com. br/o-cafe/dicas-do-cafe/dicas-de-preparacao-de-cafe/

Campos, C. C., Degáspari, C. H., \& Mottin, F. (2012). O consumo de adoçantes em produtos alimentícios na cidade de Curitiba. Visão Acadêmica, 8(2), 52-67.

Carvalho, M. W. (2017). Propriedade e simulação Gastrointestinal in vitro de iogurte Adicionado de Extrato de Estévia Rebaudiana (Bert.) em pó (Dissertação de mestrado). Universidade Federal de Santa Catarina, Florianópolis.

Casarotti, S. N. (2009). Efeito de edulcorantes sobre a qualidade de leites fermentados (Dissertação de mestrado). Instituto de Biociências, Letras e Ciências Exatas, Universidade Estadual Paulista Julio de Mesquita Filho, São José do Rio Preto.

Cavalcante, A. A. No (2017). Desidratação de cuxá em leito de espuma: avaliação da cinética de secagem e da qualidade do produto em pó (Tese de doutorado). Universidade Estadual de São Paulo, São José do Rio Preto. 
Chung, Y. S., \& Lee, M. (2013). Genotoxicity assessment of erythritol by using short-term assay. Toxicological Research, 29(4), 249-255. http://dx.doi.org/10.5487/TR.2013.29.4.249. PMid:24578795.

Cotta, R. M. M., Reis, R. S., Batista, K. C. S., Alfenas, R. C. G., \& Castro, F. A. F. (2009). Hábitos e práticas alimentares de hipertensos e diabéticos: repensando o cuidado a partir da atenção primária. Revista de Nutrição, 22(6), 823-835. http://dx.doi.org/10.1590/ S1415-52732009000600004.

Dutcosky, S. D. (2013). Análise sensorial de alimentos (4. ed.) Curitiba: Champagnat.

Federação das Indústrias do Estado de São Paulo, Instituto de Tecnologia de Alimentos. (2010). Brasil food trends 2020. São Paulo: FIESP/ ITAL. Avaible in http://www.alimentosprocessados.com.br/arquivos/ Consumo-tendencias-e-inovacoes/Brasil-Food-Trends-2020.pdf

Geraldo, A. P. G., \& Pinto-e-Silva, M. E. M. (2016). Nonnutritive sweeteners in Brazil: current use and associated factors. Revista Brasileira de Crescimento e Desenvolvimento Humano, 26(3), 297 306. http://dx.doi.org/10.7322/jhgd.122760.

Grembecka, M. (2015). Sugar alcohols - their role in the modern world of sweeteners: a review. European Food Research and Technology, 241(1), 1-14. http://dx.doi.org/10.1007/s00217-015-2437-7.

Instituto Adolfo Lutz - IAL. (2008). Métodos físico-químicos para análise de alimentos. São Paulo: IAL.

Livesey, G. (2012). Glycaemic responses and toleration. In K. O’Donnell \& M. W. Kearsley (Eds.), Sweeteners and sugar alternatives in food technology (chap. 1, pp. 3-19). Oxford: Wiley-Blackwell. http:// dx.doi.org/10.1002/9781118373941.ch1.

Marques, A. R. M., Matias, J. F., Ramos, E. C., \& Fonseca, C. S. (2012). Análise do conhecimento do consumidor diante o uso de adoçantes. Anais SIMPAC, 4(1), 61-66. Retrieved from https://academico.univicosa. com.br/revista/index.php/RevistaSimpac/article/view/192/354

Oliveira, P. B., \& Franco, L. J. (2010). Consumo de adoçantes e produtos dietéticos por indivíduos com diabetes melito tipo 2, atendidos pelo Sistema Único de Saúde em Ribeirão Preto, SP. Arquivo Brasileiro de Endocrinologia e Metabolismo, 54(5), 455-462. http://dx.doi. org/10.1590/S0004-27302010000500005.

Osman, M., Samsudin, N. S., Faruq, G., \& Nezhadahmadi, A. (2013). Factors affecting microcuttings of stevia using a mist-chamber propagation box. TheScientificWorldJournal, 2013, 940201. http:// dx.doi.org/10.1155/2013/940201. PMid:24470797.

Proença, R. P. C. (2010). Alimentação e globalização: algumas reflexões. Ciência e Cultura, Campinas, 62(4), 43-47.

Reed, D. R., \& McDaniel, A. H. (2006). The human sweet tooth. BMC Oral Health, 6(17, Suppl 1), 1-13. PMid:16934118.

Saito, T., Pereira, R. B., \& Paixão, M. P. C. P. (2013). Avaliação do nível de conhecimento de portadores de diabetes mellitus sobre adoçantes. Demetra Alimentação Nutrição \& Saúde, 8(1), 39-51. http://dx.doi. org/10.12957/demetra.2013.4239.

Santos, A. B., Bottoni, S. S., Silva, D. A., São José, J. F. B., \& Silva, E. M. M. (2017). Study of the consumers of ready-to-drink juices and fruit nectars. Food Science and Technology, 38(3), 504-512. http:// dx.doi.org/10.1590/1678-457x.09417.

Simony, R. F., \& Geraldo, A. P. G. (2014). Edulcorantes. In E. M. D. Abreu \& M. G. N. Spinelli (Eds.), Seleção e prepare de alimentos: gastronomia e nutrição. São Paulo: Editora Metha.

Suez, J., Korem, T., Zilberman-Schapira, G., Segal, E., \& Elinav, E. (2015). Non-caloric artificial sweeteners and the microbiome: Findings and challenges. Gut Microbes, 6(2), 149-155. http://dx.doi.org/10.1080/ 19490976.2015.1017700. PMid:25831243.

Yang, Q. (2010). Gain weight by going diet artificial sweeteners and the neurobiology of sugar cravings. The Yale Journal of Biology and Medicine, 83(2), 101-108. PMid:20589192.

Zanini, R. V., Araújo, C. L., \& Martinez-Mesa, J. (2011). Utilização de adoçantes dietéticos entre adultos em Pelotas, Rio Grande do Sul, Brasil: um estudo de base populacional. Cadernos de Saude Publica, 27(5), 924-934. http://dx.doi.org/10.1590/S0102-311X2011000500010. PMid:21655843. 